\title{
Environmental Issues of Livestock Production in Developing Countries: Need for Government Intervention Using the Truck Based Approach
}

\author{
Bright Okyere Ofosu ${ }^{1 *} \quad$ George Yaw Asare Addeh ${ }^{2} \quad$ Lois Tweneboa Kodua ${ }^{3}$ \\ Elizabeth Korankye ${ }^{4}$ \\ 1.School of Public Affairs and Public Administration, University of Electronic Science and Technology of \\ China,Quingshuihe Campus: No.2006 Xiyuan Ave, West Hi -Tec Zone,611731 \\ 2.School of Management and Economics, Beijing Institute of Graphic Communication, Xinghua Avenue,Band 2, \\ Daxing, Beijing, 102600 \\ 3.School of Business Administration, Zhejiang Gonghang University, No.18 Xuezheng Street, Xiasha Higher \\ Education Park,Hangzhou,Zhejiang Province,310018 \\ 4.School of Business ,Koforidua Technical University, Koforidua E/R , Ghana
}

\begin{abstract}
Globally, the natural environment faces a range of unprecedented challenges which are require a well-structured strategic approach in solving it. One of these challenges is the ever-increasing greenhouse gas emission. Currently majority of our daily activities directly or indirectly contributes to greenhouse gas emission. An effort was taken to understand better the principal function of livestock production in the pollution of the natural environment and to ascertain mitigation policies to curb the effects on human life. Theories such as the Enforcement Strategic Theory, Utilitarian Commitment Theory, Deterrence Theory, and the Social factors Commitment Based theory were used in this study. Already processed statistics, policy strategies, laws in economics as well as authors intuitive proposals and ideas were used in this study. It was ascertained that population growth, fluctuating economies, food preferences, and urbanization had imposed pressure on livestock production and the agricultural sector, thereby leading to the release of odor, ammonia, pathogens, excess phosphorus and nitrogen harming the natural environment and also contribute to greenhouse gas emission. A more significant proportion of the growth in crop production is anticipated because of a rise in the demand for livestock feed. It was found that most livestock farmers do not have a well-regulated operation in most developing countries. To reduce or eliminate these effects, the "truck-based approach" was therefore propounded and proposed to enhance the smooth movement of the livestock droppings to either the crop farm or to the processing house or to the storage room to reduce or prevent unnecessary dumping.
\end{abstract}

Keywords: Livestock Production, Environmental Issues, Green House Gas, Truck Based Approach, Government Regulation, and Developing Countries.

DOI: $10.7176 / \mathrm{JBAH} / 10-22-04$

Publication date: November $30^{\text {th }} 2020$

\section{Introduction}

Globally, the natural environment faces a range of unprecedented challenges. These challenges are huge and require a well-structured strategic approach in solving it[1]. One of these challenges is the ever-increasing greenhouse gas emission. Currently majority of our daily activities directly or indirectly contributes to greenhouse gas emission[2]. Scientists and other researchers are rigorously devising strategies to reduce this emission. One of the major contributors of this emission is the livestock production industry. Universally, livestock production covers systems where the livestock are allowed to move without restrictions to search their food to systems where they are restricted for periods up to almost three hundred and sixty-five days[3]. The livestock sector generates more than $40 \%$ of the world's agriculture (GDP) gross domestic product [4]. It creates employment for almost three billion people/ and creates a source of living for one billion of the world's population living in low-income areas[4]. Livestock is found in many economies for both dairy and beef purposes[5][6]. These livestock eject metabolic waste or droppings might be collected in the form of slurry [7] to fertilize crop farms in some countries [8], while in other countries, it is collected by hand in the form of solid excreta, and used as incineration[9]. The current demand for meat products has led to remarkable growth in the livestock industry[10][11]. In several countries, this remarkable growth of the livestock industry has caused ever-increasing concern about the pollution it causes the environment[12]. Although livestock dropping is one of the best available organic fertilizer, excessive or inappropriate applications can cause environmental glitches[13]. Nitrate leaching into the groundwater, runoffs into water bodies, and discharge of pathogenic microorganisms are three of the central problems encountered with improper management of this manure[14][15]. Aside from livestock manure being a source of important nutrients for crops, it is also a major cause of soil and air pollutant and a danger to water bodies unless well managed [16][17]. The threat of pollution as a result of poor manure management is growing due to the evolving bigger, 
provincially demanding, and more specialized livestock production [18]. The intensive system of livestock production, to a large degree, depends on the importation of livestock feed/food. Consequently, these production structures often have inadequate land areas for better removal of the manure, and therefore consider the manures to be invaluable nutrient to plants [19][20]. This situation is most common in developed countries and economies, where fertilizers are certainly obtainable and comparatively inexpensive[21].

In disparity, livestock manures are seen as a vital and more valued resource in many developing countries[22], to be specific in the sub-Saharan part of Africa. The overall quantity of livestock droppings available worldwide is enormous, so as the possible damage it causes[23][24]. The total quantity of nitrogen $(\mathrm{N})$ in manure produced yearly is as larger than the quantity of the mineral $(\mathrm{N})$ fertilizer. The quantity of phosphorus $(\mathrm{P})$, potassium $(\mathrm{K})$, and micronutrients in the livestock dung are even far greater than the amounts of mineral $(\mathrm{P}, \mathrm{K}$,$) and micronutrient$ fertilizers used per year when extrapolations are done[25]. Livestock manure is large produce because the water content inside is high; as a result, the economic costs associated with its collection, storage, as well as carriage of livestock manure are huge. Poor livestock manure management leads to the pollution of the environment and other diseases[11].

Several studies have proven that livestock contributes enormously to serious environmental problems[26], one of the environmental dangers our planet faces is the possibility for long term fluctuations in the earth's climate and temperature patterns also known as global climate change. It is projected that due to global climate change, the normal temperature of the earth might rise as far as $6.5^{\circ}$ by 2100 [27][28]. Average global temperatures have ascended considerably, and the Intergovernmental Panel on Climate Change forecasts growths in global average surface temperature to be $1.8-40 \mathrm{C}$ by 2100 [29].

\section{Research Gap}

Many developed countries, however, have come out with diverse regulations regarding how the effects of livestock droppings on the environment can be minimized. Most of the regulations explain how the livestock manure is to be put in storage, transported, distributed, applied, and also how to minimize its impact on the environment[30][31]. On the other hand, many developing and underdeveloped countries have no such regulations. Therefore about 95 percent of farmers in these countries use the raw livestock droppings as their primary source of nutrients for their crops largely due to ignorance of the effects it causes to the environment and, in some cases, low level of capital to purchase processed or manufactured fertilizers. Most of these raw livestock droppings being used as manure are washed away by rains, thereby contaminating water bodies, and some are leached into the soil which causes a serious threat to the quality of the soil, sometimes generates a kind of odor and ultimately leads to greenhouse effects[30]. Little research has been embarked on when it comes to environmental issues of livestock production[32]. The existing literature focused on only the effects but did place emphasis on how the government could help reduce its effect. Furthermore, most of the prominent works were done in the developed economies and focused on farmers to reduce the effects but did not consider a second party like the government that has greater control of the resources.

Several authors like [14], [15], [30], [33] and [34] undertook a similar study and in each of the study it was pointed out that most developed countries including U.S.A, Japan, Denmark and countries in the EU and UN have made attempts to reduce the effects of livestock manure on the environment. In their research they investigated how government can intervene in reducing this devastating problem but all emphasis was placed on the use of law and regulations but government creating avenues for the transportation, handling nor the storage.

This research aside from emphasizing on government regulation stands out to suggest that government may provide trucks to aid in the movement of the manure from the farm site to the storage point and to the processing houses. This research was motivated by the fact that most farmers in these developing and underdeveloped countries are low income earners therefore they lack the needed capital to embark on the movement and storage of livestock manure. Government aiding will be a great relief and also may prevent unnecessary dumping of livestock manure.

Therefore, the urgent need to look into this devastating menace and educate farmers about the harmful effects livestock production can pose to the general environment, bring forth the possible ways the effects can be reduced placing absolute interest on government intervention using the "truck-based approach."

\section{Environmental Issues of Livestock Production}

Meat production has increased over the past hundred years, in reaction to the ever-increasing demand associated with it[35]. All over the world, close to seventy billion animals are raised as domestically yearly, out of the seventy billion raised, close to seven million are killed for food[36], and about fifty-eight billion thrashed each year[37][38]. [36] Postulated that between 1980 and 2002, overall meat consumption all around the world doubled. According to forecasts, meat production globally is anticipated to be around 465 million tons by 2050 . Furthermore, the humane facets related to the raising and slaughtering situations of livestock in the food industry, the excessive upsurge in the intake of animal products has a massive impact on the environment[39][33][40]. The report, 
according to FAO, postulates that "The livestock industry has a noticeable influence on a global scale on soils, water, destruction of plants, and consumption of natural resources, and it has a robust effect on global warming" [27].

Table 1. Livestock droppings contribute to the pollution of the environment at different levels depending on the kind of substance involved.

\begin{tabular}{|l|c|c|c|}
\hline \multirow{2}{*}{ Substances } & \multicolumn{3}{c|}{ Degree of impact on the environmental } \\
\cline { 2 - 4 } & Local & Country & Worldwide \\
\hline Greenhouse & 0 & 0 & 1 \\
\hline Heavy metals & 1 & 1 & 0 \\
\hline Phosphorus & 1 & 1 & 0 \\
\hline Odor, $\mathrm{H}_{2} \mathrm{~S}$ & 1 & 0 & 0 \\
\hline Ammonia & 1 & 1 & 0 \\
\hline Pathogens & 1 & 1 & 0 \\
\hline Nitrate & 1 & 1 & 0 \\
\hline
\end{tabular}

Source: $[2][34] \quad 1=$ have impact......0=otherwise

Worldwide, the unbearable odor as a result of livestock production and manure management is known to be huge, but the local pollution problem because it does not affect a wide range of people. It only affects the neighbors of livestock farms. The odor is problematic for people living around livestock farms as well as the livestock farmers. This devastating problem is bloated by the adverse effect (not making the neighborhood pleasant to live and visit, creating respiratory disorders[41]) that odors from the livestock farms have on the real estate worth of neighboring residences. Odor emission reduction is an important issue that needs a special focus. The odor components are a local problem because it affects only the dwellers close to the farms[30]. Production of livestock has accounted for $55 \%$ of the global NH3 emissions [42][43]. Ammonia emission is classified as a local to a regional environmental problem/ because around $50 \%$ of the $\mathrm{NH} 3$ air is dumped near to where they were generated[44], and the formation of ammonium sulfate and ammonium nitrate elements in the air might convey the NH3 to a far distance. The release of NH3 and particularly NH4+ to land or water may bring about acidification and eutrophication of natural ecologies. Hydrogen sulfide (H2S) and NH3 in livestock habitats are a threat (causes lung and respiratory disease) to the health of farmworkers and the livestock being raised. The creation of ammonium sulfate elements in the atmosphere can be classified as both local and country health dangers[45]. Surface and ground waters might be contaminated by leaching and runoff of manure used on farms haphazardly [46]. Also, manures may be discharged directly into surface waters. The diffuse sources and direct discharge of manure nutrients to receiving waters give rise to eutrophication.

The upsurge in demand for plant nutrients needs water cleansing management in the provision of safe drinking water supplies. Thus losses of Nitrogen, Phosphorus, and other crop nutrient components to the environment are also local and a country menace. Livestock farming systems are key contributors to GHGs, CH4, and N2O. The atmospheric $\mathrm{CH} 4$ concentration has increased [47][48][49]. Indirectly, NH3 discharges also brought about N2O emissions by increasing Nitrogen content in natural ecologies[50].

There are a lot of health issues that evolve from poor manure management. Such risks include pathogens spreading between and among livestock production systems, which is likely to bring about the spread of salmonella, foot and mouth disease, and many others. Therefore when handling manure, a special attention is needed [51]. Pollution of drinking water (wells) and other shallow drinking water poses an alarming threat to human and animal health because animal manures contain many pathogens such as bacteria, viruses, and parasites[52].

\section{The Impact of Livestock Production on the Environment}

The livestock industry is the prime source of an extensive spectrum of environmental impacts [53]. The first and foremost is climate change [54]. FAO estimates that $18 \%$ of world greenhouse emission is as a result of the livestock production. According to [32], this estimate is simply too low. According to their calculations, the worldwide livestock industry is chargeable for at least $51 \%$ of the greenhouse gases discharged to the atmosphere; also, carbon dioxide emitted is estimated at 32,564 million tons. This large distinction stems in part from the FAO using outdated resources from the years 1964-2001. Nevertheless, even though greenhouse gas emissions are anticipated at handiest $18 \%$, the livestock industry is still the second-biggest polluter after the energy industry and more polluting than the transportation industry, which contributes approximately thirteen percent. Most emissions associated with the livestock industry are within the form of carbon dioxide (CO2), nitrous oxide (N2O), methane (CH4), and ammonia (NH3)[55]. Domestic animals 'obviously' release of carbon dioxide, which has been tested to be a widespread contributor to global warming [32]. Scholars warn that the world is able to likely exceed the 565 gigaton carbon dioxide restriction through the year 2030 because of a boom in livestock rearing. Besides, livestock production is chargeable for $68 \%$ of entheogenic nitrous oxide emissions; this gas stays in the environment for up to 150 years and has a 296 -fold more potential for global warming and destruction of the ozone 
layer than carbon dioxide.

Livestock discharges nearly $64 \%$ of total ammonia emissions [19], accounting drastically to acid rain and acidification of ecosystems. Livestock is likewise a notably widespread supply of methane emissions, contributing $35-40 \%$ of methane emissions globally. Methane has a 23-fold more potential for global warming than carbon dioxide[9]. The U.S. Environmental Protection Agency has proven that within the ultimate 15 years, methane emissions from pigs accelerated via $37 \%$ and releases from livestock stretched by $50 \%$ [25].

Again, while not all farm animals affect the surroundings within the same manner, the production of animal merchandise might require considerable land. Farms for rearing livestock already cover $1 / 3$ of the sector's total land and extra than two-thirds of its agricultural land [17][22]. The growing demand for animal merchandise and the dearth of land has triggered the livestock industry to become the primary cause for clearing forests. Conferring to the International Center for Forest Research (CIFOR), throughout the years 1990-2000, an area two times the scale of Portugal is lost in want of pasture. Approximately $40 \%$ of the harvested crops all around the globe are used as food for animals. [1][56]. Enormous forest clearing among different things ends up in extinctions of animals [14]. A maximum of one hundred and thirty-seven classes of flora, animals, and unique insects are lost daily as a result of the clearing of the forest. [38] Claims that from the past sixty-five million years, the greatest form of extinction is as a result of forest caring. Although it is established that the livestock industry and livestock production cause a multitude of environmental complications, its production in certain ecosystems, like arid and semi-arid lands, is the most well-adapted food production system. Production of livestock food products is the utmost cause of water pollution [57]. The tendency to increase the intake of livestock products harms environments and water bodies, mainly in developing economies. Most of the water pollution is caused by fertilizers, animal excreta, antibiotics and hormones, and pesticides utilized in food production, and runoffs [58]. The (USDA) U.S. Department of Agriculture postulated that livestock manure is a major source of pollution to water bodies [16].

\subsection{Awareness level of Environmental Pollution Caused by Livestock production}

Environmental effects, in particular, climate change as a consequence of human activities, continue to maintain an outstanding place on the international level [24]. While the entire population is conscious of environmental problems such as air and water pollution, it is miles barely privy to the environmental damages caused by the food industry. Consumers are much less aware of the impact in their food picks, through production and food distribution than of other popular problems, which include industrial pollution and natural world conservation [37]. Awareness is especially low concerning environmental pollution caused by the livestock industry. Regardless of the high recognition of consumers about the good benefits of reducing meat consumption, the environmental impact of lowering consumption is barely recognized.

Several studies conducted in Europe showed that consumers are probably anxious about animal food production, but their information in livestock issues could be very minimal and often comes from unreliable sources, and for that reason, many maintain to devour animal products [8]. In a study that examined the conduct and ideals of customers in Australia concerning food, 223 respondents were requested to rank the maximum important food-related activities for protecting environmental high-quality. 'Reducing plastic luggage' and 'compost' were found to be the most crucial activity [59]. Consumer attitudes in the direction of beef intake were tested in a have a look at that merged the results from two European Union projects [15]. The first project encompassed eight focus groups, with seven to nine contributors in each group. Overall, six-five people aged from 19 - 60 from the capital towns of France, Britain, Spain, and Germany were resentful in the deliberations. All participants were meat-eaters who consumed pork at a frequency of 'at least once a week' to 'nearly every day.'

One of the projects covered eight focused groups, with seven to nine individuals in every group. In total, sixty-five individuals between the ages of nineteen and sixty from the capital towns of Germany, France, Spain, and Britain engaged in this discussion. All the individuals were meat-eaters who fed on red meat at a frequency of 'at least once every week' to 'nearly every day.'

The discussions were supposed to extract statistics on the participants' evaluations and attitudes towards consuming meat, protection, and health. In the second undertaking, data were collected through an internet survey carried out among 2437 respondents with the age range of twenty to seventy in 5 nations: Belgium, Germany, Poland, Greece, and Denmark. The records blanketed socio-demographic facts approximately the participants, weight, and height, attitudes, and records about behavior related to meat consumption. Regarding attitudes, heavy pork consumers were in support of large-scale pork production. 'Intermediate frequency, excessive diversity' consumers were seen to have consideration to be extra environmentally conscious than the remaining groups of individuals. [15]. Occasional consumers of pork were seen to be more worried about the livestock well-being and supported production in smaller quantities. As a regulation, it was discovered that on averagely, across the entire respondents, attitudes towards the quality of the environment and animal food production had been very feeble. Even the customers who expressed the subject for the environment concerning pig production continued to devour it[13]. 


\section{Intervention and Policies in some Part of the Globe}

The main reason for extending focus outside developing economies is to solicit for policies used by other governments to at least reduce the environmental impact of livestock production. It is unarguable that the extent of environmental destruction caused by livestock production is low in developed countries because of the kind policies and interventions they put into practice. Hence reviewing some of their policies and interventions is vital not only for academic research but also for governments of developing countries.

\subsection{European Union (E.U.) countries}

Governments in countless nations have employed regulations to minimize the threats of pollution and infections in which livestock production farmers' aren't an exception [48]. This is especially the situation for countries in the European Union (E.U.). The guidelines also mirror the reality that an increasing percentage of the human populace is not acquainted with agriculture and isn't always in close contact with farmers anymore, and hence not inclined to simply accept any nuisance from the arena [33]. Furthermore, the high economic wealth of humans in rich nations permits a bigger percentage of the population to pay for products that can be produced in a more environmentally sound and animal-pleasant manner. Most of the codes of practice are geared towards recycling or the usage of the manure with the aim of encouraging environmentally-pleasant manure control and the usage of environmental technologies to alleviate its environmental effects [39].

The main intention of the 1991 Nitrates Directive is "to reduce water pollution caused by way of nitrates from agricultural sources and to prevent further pollution." This Directive obliges the Member States to adhere the subsequent steps: (i) water monitoring regarding nitrate awareness and trophic eminence; (ii) identification of waters that are susceptible to pollution and or are already polluted; (iii) description of susceptible zones (zones that drain into recognized waters); (iv) creation of codes of properly agricultural activities and motion programs (a set of actions to inhibit and decrease nitrate pollution); and (v) an overview of the prone zones and action packages (every four years). Water is referred to as polluted or at pollution risk, if nitrate concentrations in groundwater and surface waters comprise or could comprise more than $50 \mathrm{mg} \mathrm{NO3}-1-1$ if no immediate action is taken, or if ground waters, comprising freshwater bodies, estuaries, coastal and marine waters, are located to be eutrophic or in future may also grow to be eutrophic and if no action is taken.[13] The action programs to lessen pollution ought to contain obligatory measures regarding (i) periods while the use of animal manure and fertilizers to land is against the law; (ii) ability of and centers for storage of animal manure; and (iii) parameters to the quantity of animal manure and fertilizers implemented to land, which need to ensure balanced fertilization.

The 2008 Directive on Industrial Emissions concerning Integrated Pollution Prevention and Control (IPPC) uses a combined method to the management of all kinds of pollution from commercial installations. It calls for such installations to reduce all types of pollution by means of using Best Available Techniques (BAT). The IPPC directive further advises the manure management of large animal farms. These farms ought to enforce a BAT for discharge control and manure management [13][30].

The Nitrates Directive has had a large impact on livestock manure control and is one of the motives why manure management in the most superior nations inside the EU-27 is more advanced than in some parts of the world [7]. All the animal manures from constrained animals ought to be accrued and stored in leak-tight and included manure storage centers. Manures may only be applied to land in periods when the risk of leaching and surface runoff is minimal, strategies with low-emission must be used, and the application rate should not exceed a set limit.

Another E.U. Directive regarding the pollution of the ecosystem is the 2001 National Emissions Ceiling (NEC) Directive. This Directive sets ceilings for every Member State for the whole emissions in 2010 and 2020 of the four chemical pollutants (SO2, NOx, VOCs, and NH3) accountable for eutrophication, acidification, and groundlevel ozone pollution, but leaves it largely to the Member States to determine which approaches to conform to. The responses of Member States to put into effect these environmental policies have been very flexible and, in lots of cases, sluggish [30]. The delays in execution of E.U. rules nationally had been ascribed to: (i) The big variations in farming structures and environmental situations within the E.U. combined with the complexity of manure control; (ii) different understandings of the Member States regarding the objectives and measures in environmental directives and policies; (iii) unwillingness to put in force measures due to the perceived high prices to farmers and perceived low effectiveness; (iv) farmers unwillingness to present mechanisms to display compliance, due to the perceived high expenses; (v) delays in the legislature[30][6]

\subsection{United States}

Livestock production and manure control in the United States are regulated by the Clean Water Act (CWA) and the Clean Air Act (CAA). The several States have "State-specific additional rules." These states are obliged to acquire National Pollutant Discharge Elimination System (NPDES) permits underneath the CWA in the event that they discharge or offer to discharge into waters of America [60]. The certificate to discharge manure carries demands for technologies to treat the manure being discharged. After the remedy, manure from CAFOs is, as an 
instance, carried out to spray fields close to the production center and might also be discharged to nearby waters. CAFOs ought to hold an eye fixed on regulations at the emission of the subsequent gases: nitrogen dioxide (NO2), Sulfur dioxide (SO2), particulate count number (PM10 and PM2.5), carbon monoxide (C.O.), NH3, ozone, and lead. A maximum of annual emission of these gases is about at one hundred heaps year/1 is set at which the farmer has to acquire a pre-construction permit[61]. Farms of greater than 29300 head of a cow, 3200 head of poultry, and 34100 head of pork need to file their emissions of GHGs annually [62].

The National Resource Conservation Service has an established standard on manure control; this standard unit sets principles for fertilizer and manure usage and guidelines for documentation of the proper application of such nutrients. The aim is to decrease nutrient access into groundwater and the ecosystem, and at the same time, keep and boost soil fertility [63]., the manure needs to now not be used on frozen soil in surface water control areas in order to avoid runoffs [64].

\subsection{Japan}

In the case of Japan, livestock manure production sums approximately ninety million tons every 12 months [65]. To outwit the huge pollution, farms dealing in livestock in Japan are supervised by way of law [66]. This law has been carried out due to the growing proceedings of excessive pollution caused by the livestock sector since the 1970s. The essential legal guidelines controlling pollutants resultant from the livestock wastes in Japan are in brief defined below. The fundamental objective of the law on management and utilization of manure, which became enacted in 1999[65], was to encourage an appropriate remedy of manure and to promote its patronage by livestock farmers. The regulation provides sensible law requirements for the introduction of manure composting facilities, which include; sidewalls, the roof of the power, Concrete floor, and suitable length and quantity for manure stored. The law's target is augmenting the production of exact manure storing centers, which do now not leak pollution into the surroundings. Today, approximately $99.9 \%$ of Japanese livestock farms have built their centers consistent with the regulation [67].

Yet, the law does not manage the methods to be used, time to apply, or level of manure applied to fields. The water pollution management regulation enacted in 1970 set levels for the composition of livestock wastewater and or slurries, which can be discharged to nearby waters. The enactment shelters discharge of animal slurries from farms with a waste volume greater than $50 \mathrm{~m} 3$ daily. The release of dealt-with slurries to waterways is also a communal elimination technique in some Asian countries like Malaysia, Vietnam, and Taiwan. The unpleasant odor management regulation enacted in 1971 set a restriction of concentration of 22 unpleasant odors in use from livestock farms and, in some cases, industries. Nine compounds are regarded to feature to smell because of poor manure management (n-valeric acid, n-butyric acid, dimethyl sulfide, methyl mercaptan, propionic acid, hydrogen sulfide, dimethyl disulfide, isovaleric acid, and NH3). Regulation standards of the odors are set at a smell intensity of $2.5-3.5$. The intensity is qualitatively described as 0 (no scent/odor) to 5 (intense odor). The intensity degree 3 is an odor concentration, and it is straightforwardly detectable via the nose. These legal guidelines have been successful in lowering the pollution due to composting manures and due to leakage from storage and control facilities on the animal farms.

\subsection{Denmark}

In Denmark, the general aim of the law on livestock production and control of animal manure is to achieve supportable recycling of animal manure to reduce emissions of toxins to the surroundings [68]. The law forbids the release of manure to the water bodies and also the application of more than needed manure on farmlands. "Harmony Regulation" [69], was enacted in response to the E.U. Nitrate Directive requirements inside the early 1990s and postulated a maximum animal density, conforming to one hundred and forty- one hundred and seventy $\mathrm{kg}$ total nitrogen in manure (in storage) for every one hectare of land readily available for usage. Farms having a farm animal's herd above this density must have a written contract with neighboring stockless farms, wherein the manure can be applied [70].

Additionally, Denmark's law on crop fertilization, which became active on the equal time as the "Harmony Regulation," calls for farmers to carry out in-depth fertilization making plans for all fields, and crop nitrogen fertilization requirements are restricted to best eighty to eighty-five percent of the economically most excellent level to decrease the chance of over-application of fertilizer in individual farms. The enactment controls the maximum nutrient usage on each farm based on the type of soil and the farming system, composition and yield quantity estimated and additionally implements an accounting system to evaluate the minimum fertilizer efficacy of livestock manure carried out to land/ and the conforming compulsory discount within the usage of nitrogen. According to [71], Denmark's enactment on livestock manure further emphasizes on plummeting leaching and runoff, causing deficiencies of nutrients needed for crops at some point of storage and application, in addition to gaseous releases of $\mathrm{NH} 3$ and odors from the warehouse of the animal manure. Their ideas agree to the E.U. directives on livestock production, bio-waste control, and environmental safety. 


\subsection{United Nations (U.N.)}

The U.N. is the pivot of the Multilateral Environmental Agreements (MEA) on fighting climate change via the (UNFCCC) U.N Framework Convention on Climate Change. (UNFCCC) makes rules targeted at diminishing greenhouse gas emissions, comprising those from animal manure management. Also, the U.N. Economic Commission for Europe (UNECE), which clouds five conventions inclusive of the CLRTAP (Convention on Long-Range Trans boundary Air Pollution). In 1979 the CLRTAP was formed with the aim of combatting air pollutant issues. The CLRTAP has eight protocols that discover important measures to be taken by way of its fiftyone parties (international locations) to reduce their discharges of air pollution, which includes the 1999 Gothenburg Protocol. This protocol primarily focuses on the emissions of $\mathrm{SO} 2, \mathrm{O} 3, \mathrm{NOx}, \mathrm{NH} 3$, and unstable organic compounds. It sets an upper limit of the annual emissions of those toxins and requires the enactment of procedures to cut emissions. [72][73]. Approaches for estimating CH4 and $\mathrm{N} 2 \mathrm{O}$ emissions from animal manure centered on emissions factors have been invented by the IPCC (Intergovernmental Panel on Climate Change).

\section{Materials and Methods}

The authors coupled previously published papers of greenhouse gas emissions, odor appropriation, livestock manure waste, and regulations of various governments in different countries to come out with some necessary regulations for governments of developing countries to help reduce the effects of livestock production on the environment.

This study is based on the following considerations;

Consider a location with a given (constant) identical agricultural land for livestock production. An endogenous range of same livestock centers is allotted symmetrically within the area in the sense that every area has a commonplace quantity of connecting cropland acres to be had for the spreading of its waste/manure. A livestock area chooses a scale of operation, measured by the number of animals that it produces in a given length. Direct expenditure of production, not including waste control expenses, is a growing and convex feature of numbers of livestock on the farm. Producers are aggressive and receive an output price, consistent with an animal. At the district level, the price is assumed to be endogenous. It is further assumed that every area collects its waste and stores it until the waste can be unfolded on croplands or to be moved for further processing. To hold this exploration as easy as possible, the author theorizes from temporal issues by using assuming that (a) the manure accrues in the storeroom over a fixed time, and (b) an accidental rain event occurs (just before the manure is applied on fields), and can result in a spill or waste leak.

It is also assumed that each livestock facility builds a waste basin with capacity at a particular cost. The basin spills over only when the mixed volume of raw manure and rainfall exceeds the basin's storage capacity. For easiness, a basin's surface region is presumed to be relative to its quantity capacity. For example, cost considerations often imply that a set stage of basin's intensity is ideal (publicly and in private); price, therefore, equals the inverse of the ideal (fixed) basin's intensity, which is believed to be at the least as huge as the highest rainfall. It will be beneficial to think about the areas choice of basin's capability in phrases of a critical rainfall degree above which a spill takes place and under which no spilling takes place. A basin can also "leak" as a result of a structural disaster.

The chance of a leak is believed to upsurge with pressure to the basin's pollution, and health risks from spills and/or leaks cause public harm. Because possible health dangers and pollution expenditures are progressively high as the quantity of spilled and leaked waste grows, and because the ability of the local environment to engross up a spill is reduced as its volume increases, additional environmental indemnities increase with the volume of spilled/leaked content. Further consider the fact that most developing countries use lagoon and other water bodies as their primary source of water, consider the kind of odor that will evolve, consider the greenhouse effect that is will occur.

\section{Results}

This research made use of already processed statistics, adopted and modified policy strategies by other researchers and also authors intuitive proposals and ideas for developing countries to adopt in order to make it known, the unfavorable effects livestock production poses to the natural environment as well as how these effects can be at least reduced with the help of the government.

\subsection{The role of government in combatting the effects of livestock production on the environment}

The environmental issues defined in the preceding segment are mostly the end result of negligence on the part of farmers; particularly, the farmer is: (i) no longer privy to developing these problems, (ii) doesn't recognize how to avert or alleviate those harms, (iii) does no longer have the equipment and the way to alleviate those problems, and/or (iv) unearths it too steeply-priced or too complicated to avert or alleviate these problems. Therefore, the environmental menace remains in existence until actions are taken to solve or lessen its impacts[74]. 
Figure 1 Government policy cycle. (adapted from [30] and modified)

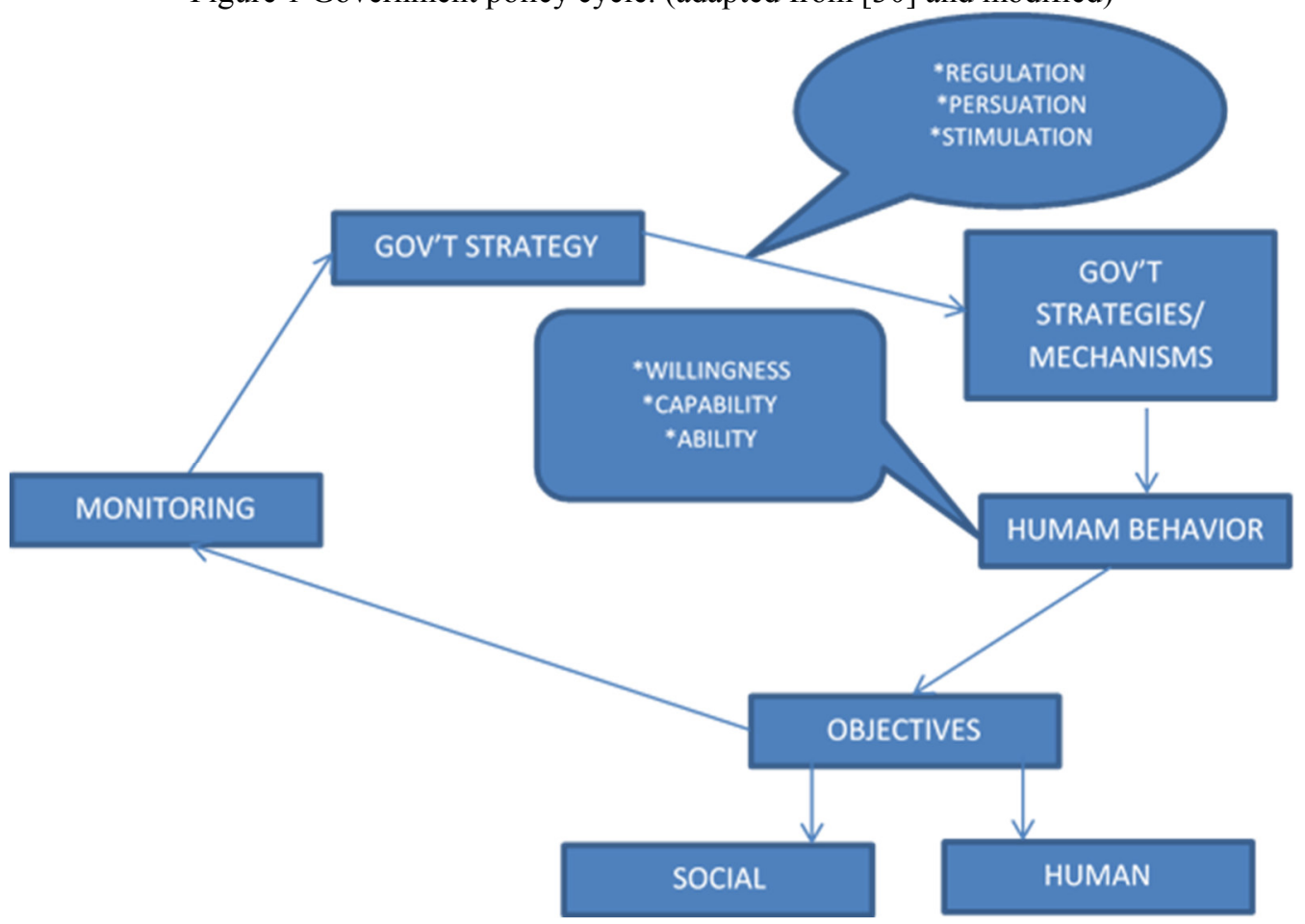

Government strategies/mechanisms are the tools to practically put into effect. The strategies are in threefold, choice which relies upon the kind of problem, the aims or goals of the policy and the capabilities and traits of the people being addressed: (i) regulatory instruments, (ii) economic or monetary instruments and (iii) persuasive instruments (as explained under).

Regulatory strategies contain a limit on the selection of the method to be used, action, and agent [47]. Regulations are compulsory measures imposing requirements on producers to acquire specific levels and requirements of environmental excellence, consisting of environmental restrictions, bans, permit necessities, most rights, or minimum responsibilities. As this work interests, governments of growing economies have the power to use those regulatory guidelines to test the operations of cattle farmers to make certain environmentally friendly operations. They are the commonly known policies used within the E.U. environmental policy (e.g., The Nitrates Directive).

\begin{tabular}{|l|l|l|}
\multicolumn{4}{l}{ Table 2: Strategies and Policies } \\
\hline Regulatory mechanisms & Economic mechanisms & communicative mechanisms \\
\hline $\begin{array}{l}\text { Planning of Public land use } \\
\text { (zoning/spatial planning) }\end{array}$ & Taxes and Levies & extension services \\
\hline Pollution principles and limits & Support in the form of subsidies & inducement and schooling \\
\hline Fertilizer parameters & export and Import rates & co-operatives \\
\hline $\begin{array}{l}\text { Best practice requirement } \\
\text { available }\end{array}$ & $\begin{array}{l}\text { Quotas and rights regarding } \\
\text { emissions }\end{array}$ & \\
\hline
\end{tabular}

Economic strategies are supposed to stimulate a certain laid down production ways. This strategy commonly exists in certain agricultural policies, which include the E.U. Common Agricultural Policy (CAP), and is also a strategy to stimulate new development. Environmental taxes and levies are rarely used in most countries. Subsidies are progressively adopted as a strategy to ensure environmentally pleasant practices. The government can reduce taxes and grant subsidies for farmers who abide by all regulations; this will help reduce the adverse impact of their production on the environment.

Communicative strategies consist of public projects to deal with environmental problems, to ensure timely flow of information, and to promote proper practices and environmental goals. This information can be furnished to producers as technical support and advice, and consumers via; this category also includes "voluntary approaches." The objective has to be monitored labeling to see whether the stated objective was attained or not. If the objective is attained, the process will be retained if otherwise, the processes and the mechanisms have to be revised. 


\subsection{How to Enforce the Strategies}

For the above strategies to be successfully enforced, it depends on the ability of the farmers to behave as projected and on the farmers' pledge to submit to the law[75]. Enforcement strategies to increase capacity comprise providing information that enables the farmers to understand what constitutes appropriate farming practices, and tumbling the costs of submitting to the regulatory principles. Policies to improve commitment are more complex (not as simple as it may seem). There are numerous bases for commitment: deterrence (coercive), remuneration (incentive), associational (social), and moral (normative), and these form the theoretical foundations for most enforcement policies[76][77].

Commitment built on deterrence and remuneration can be termed as utilitarian commitment. This is because, to some extent, every normal person (farmers) obeys or disobeys a law after comparing the costs and benefits of compliance [78]. The "Commitment" that is based on deterrence happens when the farmers view the penalties (fines, stalled projects, jail pronouncement) and comply with the regulatory requirements because the cost of not obeying is greater than the rewards such as money saved. Key elements in attaining coercive compliance embrace the certainty, speed, and severity of sanctions applied by the enforcement scheme, with research usually asserting that the punishment is extra important than the speed with which it is used or its severity [79].

Deterrence, conversely, has some shortcomings [80][81]. It needs continuous, visible surveillance so that the farmers know that defilements are likely to be noticed, and the chunk of penalties need to contain sanctions that the farmers fear. Nevertheless, the overzealous use of the deterrence can bring forth anger and retaliation, making farmers and their groups to use political pressure to lessen enforcement or abolish the regulatory program [82]. In particular, surveillance and sanctions have been most challenging when it comes to state environmental regulations because legislatures have been hesitant to appropriate resources for monitoring or to provide penalties for defilements [83][84].

Commitment based on remunerative elements also rests on utilitarian calculations. In order to build remunerative commitment, the implementation system should focus on inducements for compliance but no sanctions for noncompliance [85][86]. As contrasting to sanctions, which are typically used to cut an unwelcomed behavior such as pollution, incentives are used to upsurge or encourage a desired behavior such as apply manure at the right quantity. Typically the rewards used by enforcement systems in environmental management comprise tax abatement and cost-sharing. As with deterrence, incentives similarly have several shortcomings: They can be expensive, they may decrease altruistic behavior, and it is often tough to compute and apply a suitable reward to persuade the desired behavior and then decide whether the behavior occurred [87].

The aspiration of the farmers to get the approval of their peers and the community brings about commitment based on social factors [88]. From this viewpoint, the efficacy of sanctions stems as much from the social displeasure they produce as from any direct costs they execute. Enforcement systems can also raise social commitment through elusive incentives for compliant behavior, such as providing public awards for exceptional behavior and building positive relationships between government and the farmers based on mutual understanding and respect[76].

The regulatory theories outlined points out numerous parts of enforcement that can affect compliance and the success of government environmental regulations. Nowadays, scholarly consideration has placed much more emphasis on building reliable arguments for a particular point of view rather than on assessing their efficiency based on genuine experience in the field. As a result, the government knowing and understanding all these theories can set and enforce livestock regulations that will help the work of farmers to ensure a reduction in the pollution caused by their production.

\subsection{Ideas for Government in Developing and Underdeveloped Countries}

In addition to the already laid down measures by other countries, the government should set down regulations regarding every livestock farmer to present where the livestock droppings will be channeled. I strongly suggest every livestock farmer or producer should have a corresponding crop farmer to whom all the droppings will be channeled to reduce the effects such as green housing, contaminated water bodies, odors to a certain level, and also will help increase both crop yield and livestock production simultaneously. It will indirectly provide work for the citizens in the country because channeling the droppings to the crop farmer will involve an intermediary who does the channeling.

Incentives should be given to both livestock and crop farmers who abide by this regulation. This will not only enthuse large scale farmers to produce more, but also even farmers in the remotest villages will abide by this because of the incentives attached.

On the other hand, farmers who go contrary to this regulation will not only suffer from "no incentives" but should be punished because the health of the people comes first before any other factor.

As the government is enforcing these strict regulations, a database should first be provided for both livestock and crop farmers to make it easy for the channeling. In this regard, manure will be channeled to crop farmers closer to reduce transportation costs. 
The question now arises, how can the government help channel the droppings to the crop farmers?

It is suggested that the government has to put in place avenues for transporting the livestock manure to the crop farmers. "A truck-based approach" was adopted as a tool that can help governments of developing countries to channel manure to either the crop farmer or to the storage room.

A "truck-based approach" is simply the provision of readily available trucks to convey the droppings to the farmer at the least possible price. The trucks can be owned by both private individuals and the government, but the activity should be supervised by the government. The main reason for the activity being supervised or embarked on by the government is to prevent price extortion or exploitation (a price manipulation by private individuals owning a truck).

Figure 2: The truck-based approach

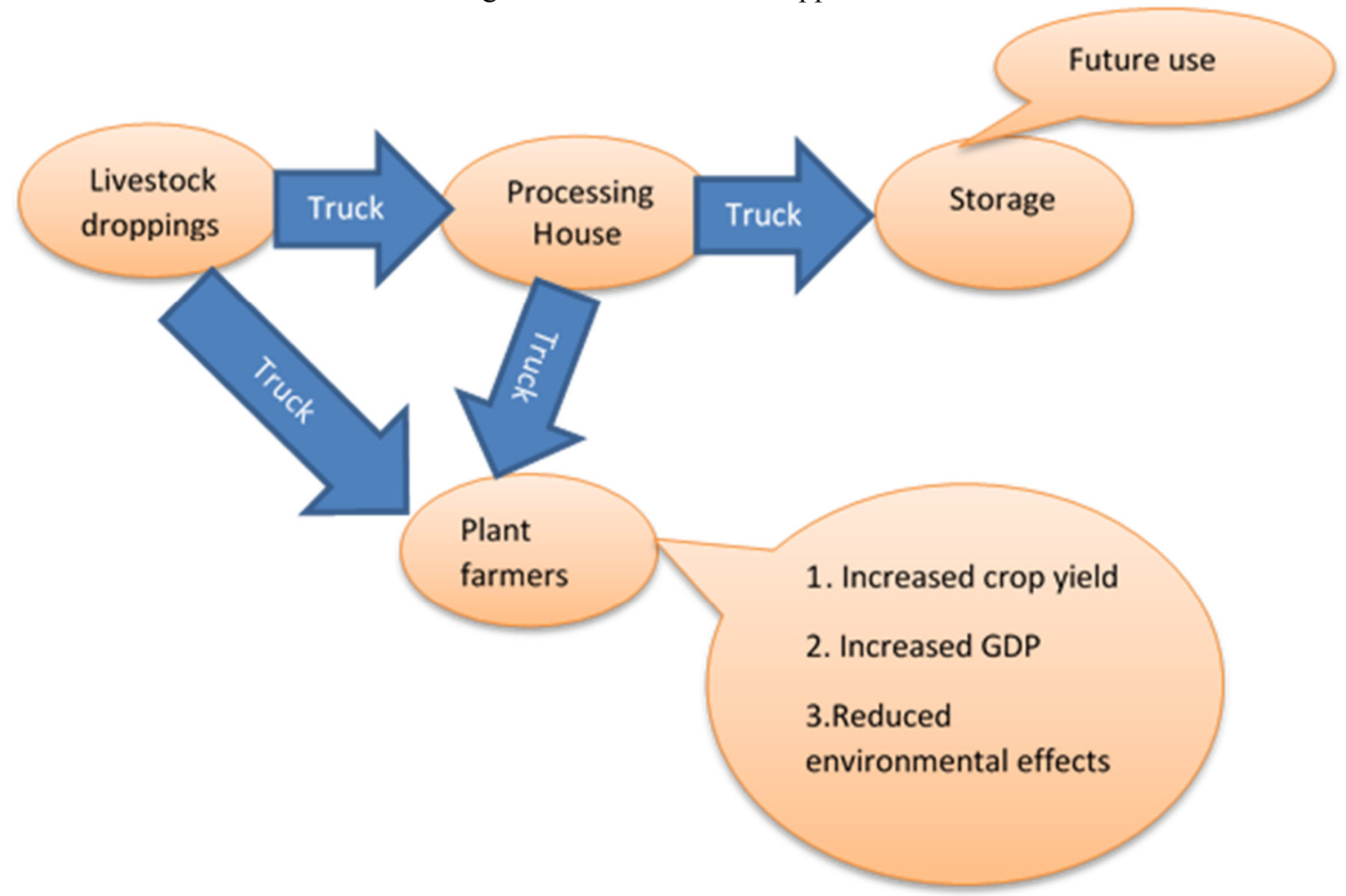

In the cases where the droppings need further processing, the government should help provide avenues for transforming the raw dropping to usable manure to reduce all the harmful effects, to ensure better living, and to help boost the GDP by ensuring high farming yields because of good manure.

Furthermore, where there is the need to store the manure for future use because of future uncertainties, the government should work hand in hand with farmers to build a storage facility for any future event. If possible, every region should have a general storeroom built by the government for hosting the excess manure. Since the database is already available, it will be easier to know how big to build the storage facility. 
7.4 Need for government intervention in the environmental issues of livestock production in developing economies/countries

Figure 3

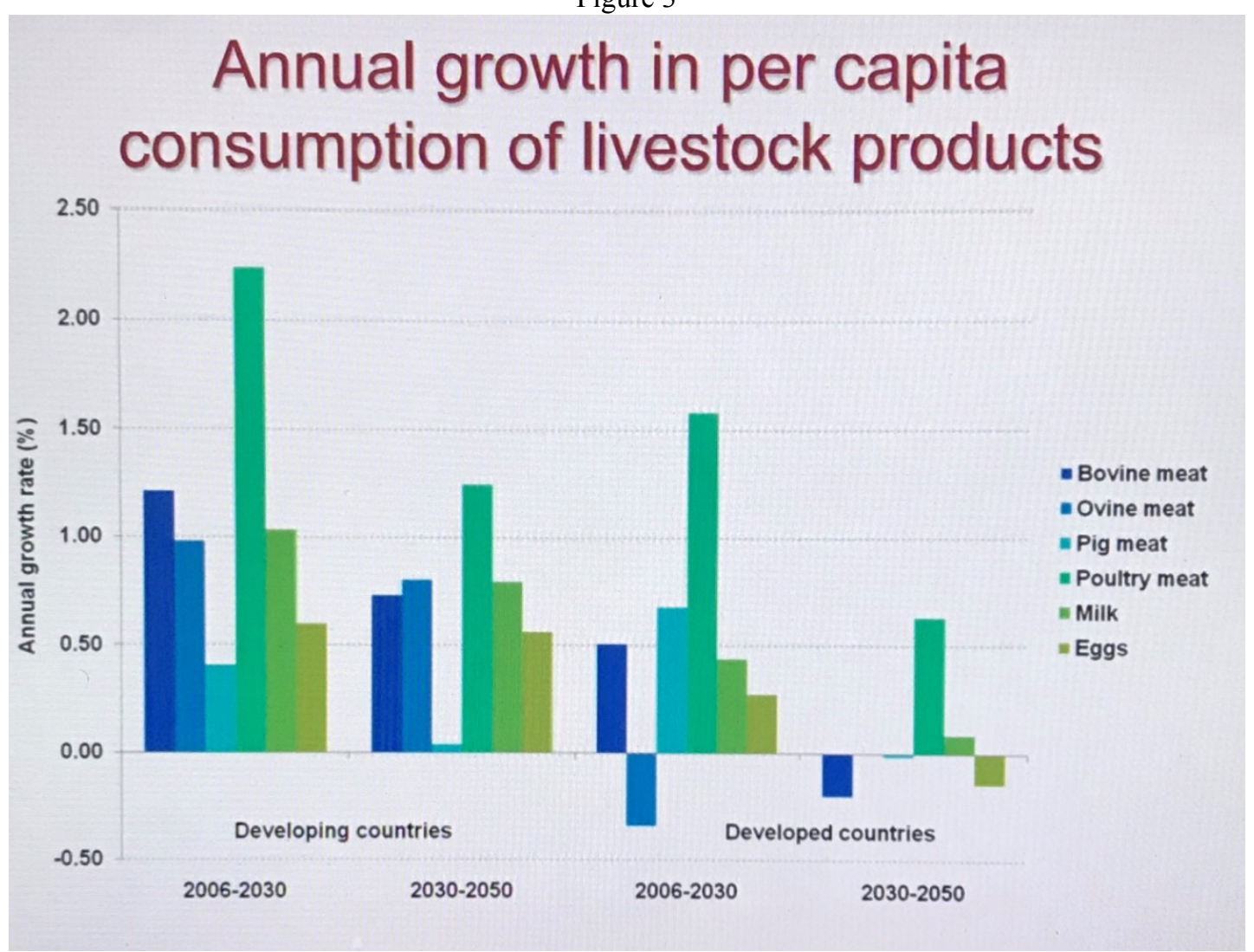

Source: international livestock research institute

As shown in figure 3, there will be a significant increase in the per capita consumption of livestock products, especially in poultry meat from now to 2050 [89]. This is highly due because people's income is increasing. A rational consumer will consume more or increase consumption when his/her income level increases (ceteris paribus). So as incomes of people continue to increase their consumption will increase as well. Aside from this law of rationality, people are developing a special taste and preference for livestock products, which will make the consumption upsurge. Most people are negligent of the demerits of consuming livestock products at a high level and the serious effects livestock production brings to the environment as a whole. 
Figure 4

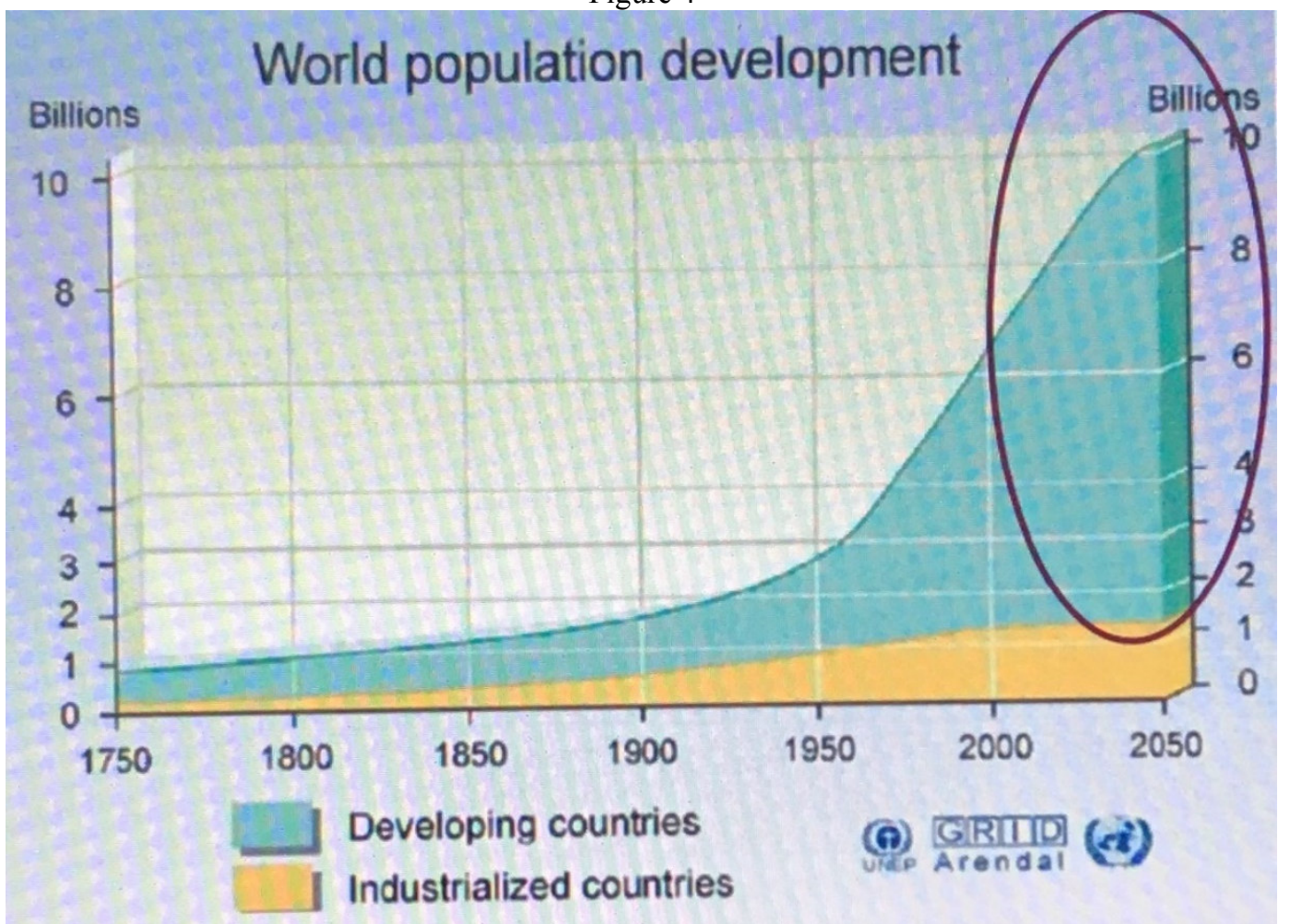

This figure presents the population development of both developing and industrialized countries. It should be noted on the record that developing countries will have their population increasing because most people see children as assets in some parts of the developing countries, and there is no regulation by the government regulating birth control. Developing countries will continue to increase in population, which will lead to an increase in consumption, and considering the mentality of livestock product consumption, an upsurge of livestock product consumption will be the order of the day, thereby increasing the unfavorable effects of livestock production. It is clear that developing countries' population will be almost ten times that of industrialized, so it is high time developing countries take serious measures to curb and prevent the effects of livestock production.

Figure 5

\section{The Livestock Revolution:}

\section{A strong increase in demand for meat and milk as} income grows

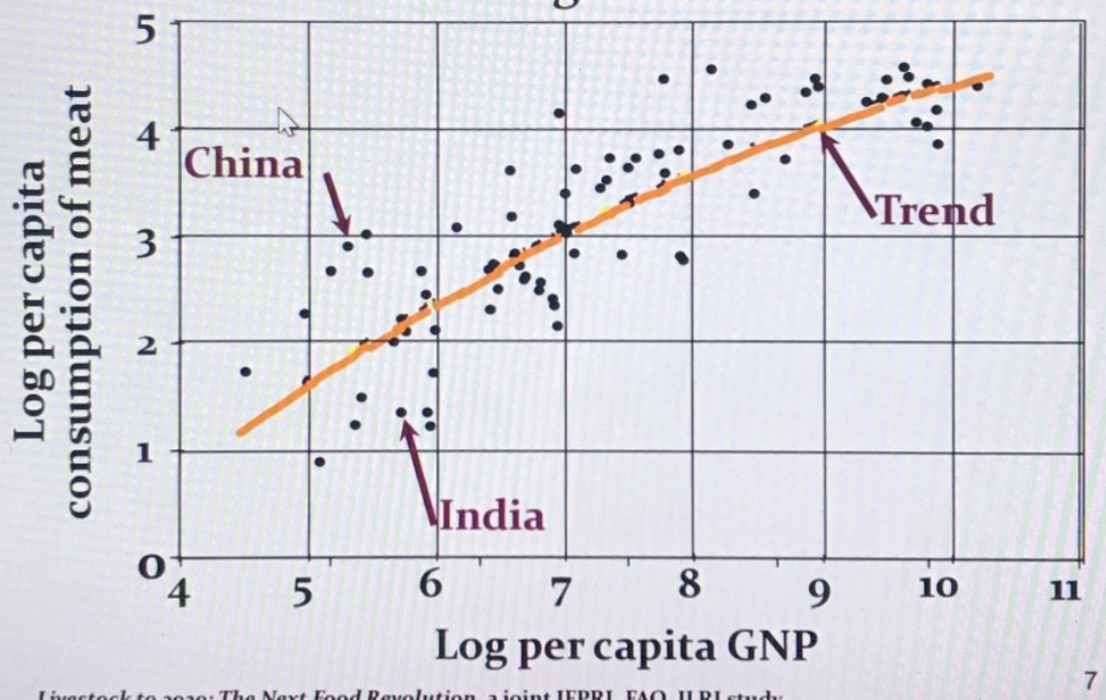

Livestock to 2020: The Next Food Revolution, a joint IFPRI, FAO, ILRI study. 
As it was postulated earlier, when the income of the rational consumer increases, consumption also increases (all other things being constant). Looking at the trend, the consumption of meat is increasing asymmetrically with the level of income. Therefore the effects of livestock production, if not carefully dealt with, will destroy the environment, take away precious lives and innocent souls.

Table 3: demand for livestock products to 2050

\begin{tabular}{|l|l|l|l|l|l|}
\hline & & Annual per capita consumption & \multicolumn{2}{l|}{ Total consumption } \\
\hline & year & Meat $(\mathrm{kg})$ & Milk $(\mathrm{kg})$ & Meat $(\mathrm{mt})$ & Milk $(\mathrm{mt})$ \\
\hline Developed & 2002 & 28 & 44 & 137 & 222 \\
& 2050 & 44 & 78 & 326 & 585 \\
\hline Developing & 2002 & 78 & 202 & 102 & 265 \\
& 2050 & 94 & 216 & 126 & 295 \\
\hline
\end{tabular}

Source: [90]

Unarguably, meat consumption in developing countries is estimated to surpass that of developed countries, in the same way, the consequences of livestock production, so there is an urgent need for developing countries to put in place measures to control the effects thereof.

\section{Summary}

Regulation and rules on manure supervision had been enacted in many rich and developed nations and economies, where livestock manure has to turn out to be a waste in preference to a precious aid of nutrient and organic matter. These policies define how the livestock manure is to be handled and stored and how the fertilizer must be used on farmland and what sort of manure may be applied extremely. On the other hand, many developing or underdeveloped countries and economies do not have regulations related to livestock manure control, in part because the manure continues to be treated as a precious supply of nutrients and organic rely, however, the outcomes aren't effectively-regarded.

Government regulations regarding proper livestock manure management range from countrywide through regions and to locals. The European Union nitrates directive suggests the manner in which the manure needs to be stored and sets limits for the quantity of manure implemented or used on farmlands. The NEC Directive establishes parameters for the amounts of NH3 than can be emitted. In the U.S., anaerobically processed manure may be used on small areas of land without accounting for the number of crop nutrients used on the farmland. Also, in Japan, leaches to surface and ground waters is considered acceptable, if the leached manures have pollutant concentrations underneath thresholds set by way of the regulation. Conversely, the release of any kind of farm animals' manure is prohibited in the E.U. Farmers in Denmark are only permitted to use manure to farms with plants, and the quantities applied, and the timing is rigorously regulated and controlled through the government, the aim being to ensure recycling and the compost value of the crop nutrients in manure.

In most instances, the emphasis is placed on the legal aspects without placing much focus on who is responsible for conveying the manure from the livestock farmer. A truck-based system was introduced to enhance the movement of the manure from the livestock farmer either to the crop farmer, for further processing or to the storage room. The truck-based system will help to prevent manure from being left on livestock farms, which can cause serious environmental effects.

\section{Limitations of the study}

The research placed prior emphasis on the government intervention by means of providing trucks to convey the manure but it did not make any proposal for the government to intervene in the arena of providing storage facilities to aid in the manure storage. Therefore future research can focus on government building storage facilities for keeping the manure for future use.

Furthermore, since the research concentrates on developing and underdeveloped countries, the results and proposals are not intended to be generalized to include the developed countries. Though the findings might not represent the developed countries, the results and proposals are still important in giving signals or informing developed countries about how the government can intervene to reduce the adverse impacts of livestock production on the environment.

\section{References}

[1] I. Weindl, H. Lotze-Campen, A. Popp, B. Bodirski, and S. Rolinski, "Impacts of livestock feeding technologies on greenhouse gas emissions," in Climate Change in World Agriculture: Mitigation, Adaptation, Trade and Food Security, 2010.

[2] D. Chadwick et al., "Manure management: Implications for greenhouse gas emissions," Anim. Feed Sci. Technol., 2011, doi: 10.1016/j.anifeedsci.2011.04.036.

[3] C. J. Peters, J. A. Picardy, A. Darrouzet-Nardi, and T. S. Griffin, "Feed conversions, ration compositions, and land use efficiencies of major livestock products in U.S. agricultural systems," Agric. Syst., 2014, doi: 
10.1016/j.agsy.2014.06.005.

[4] FAO, "Socio-economic context and role of agriculture," Cambodia Ctry. fact sheet food Agric. policy trends, 2014.

[5] N. Alexandratos, "World agriculture : towards 2030/2050 Interim report," 2006.

[6] M. E. Gavito et al., "Ecology, technology and innovation towards sustainability: challenges and perspectives in Mexico," Rev. Mex. Biodivers., 2017, doi: 10.1016/j.rmb.2017.09.001.

[7] M. C. Rufino, P. Brandt, M. Herrero, and K. Butterbach-Bahl, "Reducing uncertainty in nitrogen budgets for African livestock systems," Environmental Research Letters. 2014, doi: 10.1088/17489326/9/10/105008.

[8] S. Salaheen, N. Chowdhury, I. Hanning, and D. Biswas, "Zoonotic bacterial pathogens and mixed croplivestock farming," in Poultry Science, 2015, doi: 10.3382/ps/peu055.

[9] "SOLID WASTE MANAGEMENT: A STUDY IN A COMPANY THAT OPERATES IN THE CITY OF XANXERÊ AND REGION," SOLID WASTE Manag. A STUDY A Co. THAT Oper. CITY XANXERE Reg., 2015, doi: 10.5902/2236117014783.

[10] M. A. Shah, S. J. D. Bosco, and S. A. Mir, "Plant extracts as natural antioxidants in meat and meat products," Meat Science. 2014, doi: 10.1016/j.meatsci.2014.03.020.

[11] N. Fiala, "Meeting the demand: An estimation of potential future greenhouse gas emissions from meat production," Ecol. Econ., 2008, doi: 10.1016/j.ecolecon.2007.12.021.

[12] L. Cao et al., "Environmental impact of aquaculture and countermeasures to aquaculture pollution in China," Environmental Science and Pollution Research. 2007, doi: 10.1065/espr2007.05.426.

[13] D. Nayak et al., "Management opportunities to mitigate greenhouse gas emissions from Chinese agriculture," Agric. Ecosyst. Environ., 2015, doi: 10.1016/j.agee.2015.04.035.

[14] T. G. Reichenau, C. W. Klar, V. I. S. Lenz-Wiedemann, P. Fiener, and K. Schneider, "Nitrate leaching," in Regional Assessment of Global Change Impacts: The Project GLOWA-Danube, 2016.

[15] M. E. Stuart, D. C. Gooddy, J. P. Bloomfield, and A. T. Williams, "A review of the impact of climate change on future nitrate concentrations in groundwater of the UK," Science of the Total Environment. 2011, doi: 10.1016/j.scitotenv.2011.04.016.

[16] a McLeod and N. F. and A. O. of the United, World Livestock 2011 Livestock in food security World. 2011.

[17] X. Deng, A. C. Spieler, and D. Tsang, "Livestock," in Commodities: Markets, Performance, and Strategies, 2018.

[18] M. 2010 Fairbairn, "Framing Resistance: International Food regimes and the roots of food sovereignty.," Food Sovereignty: Reconnecting Food, Nature and Community. 2010.

[19] K. F. Davis and P. D'Odorico, "Livestock intensification and the influence of dietary change: A caloriebased assessment of competition for crop production," Sci. Total Environ., 2015, doi: 10.1016/j.scitotenv.2015.08.126.

[20] C. G. Scanes, “Animal Agriculture: Livestock, Poultry, and Fish Aquaculture,” in Animals and Human Society, 2018.

[21] H. E. Jahnke, "Agricultural development in the seasonal Tropics [Landwirtschaftliche entwicklung in den sommerfeuchten Tropen]," Geogr. Rundsch., 2000.

[22] P. K. Thornton, "Livestock production: Recent trends, future prospects," Philosophical Transactions of the Royal Society B: Biological Sciences. 2010, doi: 10.1098/rstb.2010.0134.

[23] M. Scheftelowitz, D. Thrän, D. Version, R. B. Shrestha, G. M. Ofori, and R. Zhang, "Sustainable Energy for All Action Plan - Ghana," Agriculture, 2015, doi: 10.3390/agriculture6020020.

[24] FAO, "Environmental opportunities for insect rearing for food and feed," Edible insects Edible insects Futur. Prospect. forfood feeed Secur., 2006.

[25] M. M. Rojas-Downing, A. P. Nejadhashemi, T. Harrigan, and S. A. Woznicki, "Climate change and livestock: Impacts, adaptation, and mitigation," Climate Risk Management. 2017, doi: 10.1016/j.crm.2017.02.001.

[26] M. E. Gavito et al., "Ecología, tecnología e innovación para la sustentabilidad: retos y perspectivas en México," Rev. Mex. Biodivers., 2017, doi: 10.1016/j.rmb.2017.09.001.

[27] M. K. Roul, R. Mishra, and A. Das, "IMPACT OF INCREASE IN GREENHOUSE GASES ON GLOBAL WARMING AND ITS REMEDIES,” JETIR1712134 J. Emerg. Technol. Innov. Res., 2017.

[28] M. Nurul and I. Director, "Climate Change and its impact on Bangladesh," J. Pharmacogn. Phytochem., 2020.

[29] IPCC, Climate Change 2007 Synthesis Report. 2007.

[30] S. O. Petersen et al., "Recycling of livestock manure in a whole-farm perspective," Livest. Sci., 2007, doi: 10.1016/j.livsci.2007.09.001.

[31] A. Kijlstra and I. A. J. M. Eijck, “Animal health in organic livestock production systems: A review," NJAS 
- Wageningen Journal of Life Sciences. 2006, doi: 10.1016/S1573-5214(06)80005-9.

[32] R. Goodland and J. Anhang, "Livestock and Climate Change - What if the key actors in climate change are cows, pigs, and chickens? WorldWatch November/December report," Worldwatch Institute, 2010. .

[33] B. Notarnicola, G. Tassielli, P. A. Renzulli, V. Castellani, and S. Sala, "Environmental impacts of food consumption in Europe," J. Clean. Prod., 2017, doi: 10.1016/j.jclepro.2016.06.080.

[34] S. G. Sommer, M. L. Christensen, T. Schmidt, and L. S. Jensen, Animal Manure Recycling: Treatment and Management. 2013.

[35] R. C. Ilea, "Intensive livestock farming: Global trends, increased environmental concerns, and ethical solutions," J. Agric. Environ. Ethics, 2009, doi: 10.1007/s10806-008-9136-3.

[36] J. B. Gaughan, "Basic principles involved in adaption of livestock to climate change," in Environmental Stress and Amelioration in Livestock Production, 2012.

[37] S. S. Amjid, M. Q. Bilal, M. S. Nazir, and A. Hussain, "Biogas, renewable energy resource for Pakistan," Renewable and Sustainable Energy Reviews. 2011, doi: 10.1016/j.rser.2011.02.041.

[38] S. De Smet, "Meat, poultry, and fish composition: Strategies for optimizing human intake of essential nutrients," Anim. Front., 2012, doi: 10.2527/af.2012-0057.

[39] E. Röös, L. Ekelund, and H. Tjärnemo, "Communicating the environmental impact of meat production: Challenges in the development of a Swedish meat guide," J. Clean. Prod., 2014, doi: 10.1016/j.jclepro.2013.10.037.

[40] I. Zabalza Bribián, A. Valero Capilla, and A. Aranda Usón, "Life cycle assessment of building materials: Comparative analysis of energy and environmental impacts and evaluation of the eco-efficiency improvement potential," Build. Environ., 2011, doi: 10.1016/j.buildenv.2010.12.002.

[41] A. R. Mosier, "Exchange of gaseous nitrogen compounds between agricultural systems and the atmosphere," Plant Soil, 2001, doi: 10.1023/A:1004821205442.

[42] X. Zhang, Y. Lu, Q. Wang, and X. Qian, "A high-resolution inventory of air pollutant emissions from crop residue burning in China," Atmos. Environ., 2019, doi: 10.1016/j.atmosenv.2019.06.009.

[43] S. M. K. Naqvi and V. Sejian, Livestock and Global Climate Change. 2008.

[44] L. S. Timothy Robinson, Philip Thorton, Gianluca Franceschini, Russ Kruska, Federoca Chiozza, An Notenbaert, Giuliano Cecchi, Mario Herrero, Michael Epprecht, Steffen Fritz, Liang You, Giulia Conchedda, Global Livestock Production Systems. 2011.

[45] J. W. Erisman and M. Schaap, "The need for ammonia abatement with respect to secondary PM reductions in Europe," Environ. Pollut., 2004, doi: 10.1016/j.envpol.2003.08.042.

[46] H. Graveland, J. A. Wagenaar, K. Bergs, H. Heesterbeek, and D. Heederik, "Persistence of livestock associated MRSA CC398 in humans is dependent on intensity of animal contact," PLoS One, 2011, doi: 10.1371/journal.pone.0016830.

[47] C. Liu, M. Lu, J. Cui, B. Li, and C. Fang, "Effects of straw carbon input on carbon dynamics in agricultural soils: A meta-analysis," Glob. Chang. Biol., 2014, doi: 10.1111/gcb.12517.

[48] J. LELIEVELD, P. J. CRUTZEN, and F. J. DENTENER, "Changing concentration, lifetime and climate forcing of atmospheric methane," Tellus B, 1998, doi: 10.1034/j.1600-0889.1998.t01-1-00002.x.

[49] I. 2007, Fourth Assessment Report of the Intergovernmental Panel on Climate Change (IPCC). 2007.

[50] IPCC, Global warming of $1.5^{\circ} \mathrm{C} .2018$.

[51] A. Albihn, "Recycling biowaste--human and animal health problems.," Acta veterinaria Scandinavica. Supplementum. 2001.

[52] N. . Marshall, P. . Marshall, J. Tamelander, D. Obura, D. Malleret-King, and J. E. Cinner, "A Framework for Social Adaptation to Climate Change Sustaining Tropical Coastal Communitites and Industries," 2010.

[53] R. C. Ilea, "Intensive livestock farming: Global trends, increased environmental concerns, and ethical solutions," in Applied Ethics: A Multicultural Approach: Sixth Edition, 2017.

[54] A. J. McMichael, J. W. Powles, C. D. Butler, and R. Uauy, "Food, livestock production, energy, climate change, and health," Lancet. 2007, doi: 10.1016/S0140-6736(07)61256-2.

[55] J. M. F. Johnson, A. J. Franzluebbers, S. L. Weyers, and D. C. Reicosky, "Agricultural opportunities to mitigate greenhouse gas emissions," Environmental Pollution. 2007, doi: 10.1016/j.envpol.2007.06.030.

[56] M. J. Spilsbury, "CIFOR. The sustainability of forest management: Assessing the impact of cifor criteria and indicators research," in International Research on Natural Resource Management: Advances in Impact Assessment, 2007.

[57] B. Machovina, K. J. Feeley, and W. J. Ripple, "Biodiversity conservation: The key is reducing meat consumption," Science of the Total Environment. 2015, doi: 10.1016/j.scitotenv.2015.07.022.

[58] X. P. C. Vergé, C. De Kimpe, and R. L. Desjardins, "Agricultural production, greenhouse gas emissions and mitigation potential," Agric. For. Meteorol., 2007, doi: 10.1016/j.agrformet.2006.06.011.

[59] M. A. Khan, M. Chander, and D. Bardhan, "Willingness to pay for cattle and buffalo insurance: An analysis of dairy farmers in central India," Trop. Anim. Health Prod., 2012, doi: 10.1007/s11250-012- 
0240-Z

[60] EPA, "Emission Factors for Greenhouse Gas Inventories," 2014. doi: 10.1177/0160017615614897.

[61] S. E. Zirka et al., "Fault section estimation in distribution systems using biogeography- based," Electr. Power Syst. Res., 2009, doi: 10.1002/etep.

[62] J. Downie and W. Stubbs, "Corporate carbon strategies and greenhouse gas emission assessments: The implications of scope 3 emission factor selection,” Bus. Strateg. Environ., 2012, doi: 10.1002/bse.1734.

[63] Natural Resource Conservation Service, "Sampling Soils for Nutrient Management," Manure as a Resour. Ser., 2012, doi: http://www.mt.nrcs.usda.gov.

[64] B. Grizzetti, D. Lanzanova, C. Liquete, A. Reynaud, and A. C. Cardoso, "Assessing water ecosystem services for water resource management," Environ. Sci. Policy, 2016, doi: 10.1016/j.envsci.2016.04.008.

[65] R. Prasad, "Rice-Wheat Cropping Systems," Advances in Agronomy. 2005, doi: 10.1016/S00652113(05)86006-7.

[66] G. HILTON, "Report of the Veterinary Director General, Health of Animals Branch, Department of Agriculture, for the Year ending March 31, 1931.," Report of the Veterinary Director General, Health of Animals Branch, Department of Agriculture, for the Year ending March 31, 1931. 1931.

[67] M. B. Kannan, V. Solovieva, and V. Blank, "The small MAF transcription factors MAFF, MAFG and MAFK: Current knowledge and perspectives," Biochimica et Biophysica Acta - Molecular Cell Research. 2012, doi: 10.1016/j.bbamcr.2012.06.012.

[68] T. Dalgaard et al., "Policies for agricultural nitrogen management-trends, challenges and prospects for improved efficiency in Denmark," Environ. Res. Lett., 2014, doi: 10.1088/1748-9326/9/11/115002.

[69] P. Christensen, L. Kørnøv, and E. H. Nielsen, "Between governance and government: Danish EIA in uncharted waters," J. Environ. Assess. Policy Manag., 2012, doi: 10.1142/S1464333212500214.

[70] T. Dalgaard et al., "Policies for agricultural nitrogen management-trends, challenges and prospects for improved efficiency in Denmark Related content Synthesis and review: Tackling the nitrogen management challenge: from global to local scales," Environ. Res. Lett, 2014, doi: 10.1088/1748-9326/9/11/115002.

[71] N. Halberg, J. E. Hermansen, I. S. Kristensen, J. Eriksen, and N. Tvedegaard, "Comparative environmental assessment of three systems for organic pig production in Denmark," Proc. Org. Agric. Asia 2008, 2008.

[72] UNECE, "Climate Change Impacts and Adaptation for International Transport Networks," Expert Gr. Rep., 2013.

[73] U. FAO, "European Forest Sector Outlook Study," UN FAO Rep., 2005.

[74] N. F. Suttle, Mineral nutrition of livestock: Fourth edition. 2010.

[75] A. Challinor, T. Wheeler, C. Garforth, P. Craufurd, and A. Kassam, "Assessing the vulnerability of food crop systems in Africa to climate change," Clim. Change, 2007, doi: 10.1007/s10584-007-9249-0.

[76] R. Wittek, U. Schimank, and T. Gro, "Governance - A sociological perspective," in New Forms of Governance in Research Organizations: Disciplinary Approaches, Interfaces and Integration, 2007.

[77] P. C. Fiss et al., "APPROACH TO TYPOLOGIES IN ORGANIZATION RESEARCH,” Source Acad. Manag. J. Acad. Manag. J. tention (e.g, 2011.

[78] G. J. Stigler, "The case, If Any, for economic literacy," J. Econ. Educ., 1983, doi: 10.1080/00220485.1983.10845027.

[79] J. Höglund and J. Höglund, "Ecological genomics," in Evolutionary Conservation Genetics, 2009.

[80] G. I. BALCH, "THE STICK, THE CARROT, AND OTHER STRATEGIES: A Theoretical Analysis of Governmental Intervention," Law Policy, 1980, doi: 10.1111/j.1467-9930.1980.tb00203.x.

[81] J. K. Balch, B. A. Bradley, C. M. D’Antonio, and J. Gómez-Dans, "Introduced annual grass increases regional fire activity across the arid western USA (1980-2009)," Glob. Chang. Biol., 2013, doi: 10.1111/gcb.12046.

[82] J. Lynxwiler, N. Shover, and D. A. Clelland, "The Organization and Impact of Inspector Discretion in a Regulatory Bureaucracy,”Soc. Probl., 1983, doi: 10.2307/800112.

[83] S. W. Webster, N. Shover, D. A. Clelland, and J. Lynxwiler, "Enforcement or Negotiation: Constructing a Regulatory Bureaucracy.," Soc. Forces, 1988, doi: 10.2307/2579581.

[84] B. G. Peters, C. Hood, J. Burke, N. Shover, D. Clelland, and J. Lynxwiler, "Designing Bureaucracies,” J. Policy Anal. Manag., 1987, doi: 10.2307/3323359.

[85] K. Cook, M. James, R. Lee, K. Cook, M. James, and R. Lee, "Road Traffic Act 1988," in Core Statutes on Criminal Law, 2015.

[86] B. J. Cook and B. D. Wood, "Principal-Agent Models of Political Control of Bureaucracy," Am. Polit. Sci. Rev., 1989, doi: 10.2307/1962069.

[87] S. Balt, J. Meuldijk, and W. E. Renkema, "Kinetics and mechanism of complex formation between 1-(2hyroxyphenyl)-3,5-diphenylformazan and ammineaquonickel(II) complexes," Inorganica Chim. Acta, 1980, doi: 10.1016/S0020-1693(00)90524-3.

[88] J. F. Rochecouste, P. Dargusch, and C. King, "Farmer perceptions of the opportunities and constraints to 
producing carbon offsets from Australian dryland grain cropping farms," Australas. J. Environ. Manag., 2017, doi: 10.1080/14486563.2017.1379037.

[89] I. F. P. Research Institute (IFPRI), “2017 Global Food Policy Report,” 2017. doi: 10.2499/9780896292529.

[90] B. et al Phillips, "Oxford Centre for Evidence-based Medicine - Levels of Evidence ( March 2009 ) for Evidence-based Oxford Centre Medicine - Levels of Evidence," Centre for Evidence Based Medicine, 2014. . 